\title{
Water Quality Assessment Along Lower Hlaing River
}

\author{
Cho Cho Thin Kyi ${ }^{1}$, Theigyi Ye Myint ${ }^{2}$ \\ Associate Professor, Department of Civil Engineering, Yangon Technological University, Yangon, Myanmar \\ ccthinkyi@gmail.com $^{\text {I }}$ \\ Assistant Lecturer, Department of Civil Engineering, Yangon Technological University, Yangon, Myanmar \\ tgym5595@gmail.com $^{2}$
}

\begin{abstract}
In this study, water quality of Hlaing River was monitored along the downstream reach during low flow periods and water samples were collected once a week during January and February. Stations for sample collection were fixed after site survey. There are altogether 14 stations to analyse water quality of the study river reach. The monitoring program includes collection of samples from seven locations along the river into which seven streams discharge. These samples were analysed for a number of water quality parameters such as temperature, total dissolve solid, total suspended solid, Conductivity, Salinity, pH, BOD, COD and Arsenic. The results of water quality parameters showed significant variation in water quality of the river and the water quality monitoring data were compared to the water quality standards for different uses. It is found that water quality of Hlaing River deteriorates and doesn't meet the requirements for conserving of living environment due to the pollution from the tributary streams which received wastewater from adjacent industrial zones and newly Satellite town.
\end{abstract}

Keywords-Conductivity, BOD, COD, DO, low flow periods

\section{INTRODUCTION}

$\mathrm{S}$ urface water quality is influenced by various natural processes and anthropogenic activities. Many places in Myanmar, wastewater is discharged into the natural water bodies which can assimilate and dilute the harmful constituents of the effluents. Thus, municipal and industrial demand for freshwater rises, as effluents of low quality are increasingly disposed without proper treatment into the natural water bodies resulting in further degradation of their water quality.

Rivers and streams are important components of natural environment. They have many values such as economic (fishing, electricity generation, transport and irrigation), aesthetic (recreation), ecological (biodiversity), water for consumption (water supply for domestic and industrial uses) and conveying wastewater discharges (treated or untreated), urbanization and unsustainable water consumption. Both the effluents flow directly into the nearby natural water bodies (rivers or canals) through open drains.

The water quality degradation is evident as a result of effluents added in a water body. But the response of water body in terms of its quality for different uses may vary due to numerous factors. These factors include the nature of water body (lake, river, reservoir, sea, etc.), water quality status of the receiving water body, availability of flow, alteration in natural flow, quantity and quality of the added effluents, climatic factors and so on. Some of these factors may be the key determinant of water quality in one condition but they may have a little or no impact in a different condition.

\section{GENERAL DESCRIPTION OF THE STUDY AREA}

Yangon City is bounded on the south, southeast and southwest by the Yangon, Hlaing, and Bago rivers. The Nga Moeyeik Creek flows into the Yangon City and changes its name to Pazyndaung Creek and penetrates the center of the city to the Bago River. The river system of the western side of Greater Yangon is more complicated. A few of tidal rivers, namely, the Kok Ko Wa River, the Pan Hlaing River, Hlaing River, and the Twante Canal flow into the Yangon River. The river system in and around Greater Yangon is schematically shown in Figure 1.

Catchment area of the study river is about $700 \mathrm{~km}^{2}$ and length is $12 \mathrm{~km}$ long. There are several industrial zones were developed along the bounded rivers and most of the wastewater discharge without proper treatment to the natural water body. Population density increase significantly due to the development of industrial zones and housing projects domestic wastewater and dumping of garbage into drains are also the source of pollution of it. 


\section{METHODS AND METHODOLOGY}

Samples were collected from locations which are upstream of the main inlets along the reach of the river and contributing inlets. The flow of river and the contributing drains were observed during low flow months (January and February). The water quality assessment showed the variation of individual water quality parameters, self purification capacity of the receiving river and their comparison with the water quality guidelines for different uses.

\section{A. Assessment Strategy}

Required parameters to be tested were identified and pre-sampling visits were made to:

- Identify the location of various surface drain (point source pollution ).

- Select appropriate sampling stations along the river.

- Take geological co-ordinates of the selected sampling stations.

- Estimate different equipments and material required during the monitoring program.

- Plan the frequency of sampling.

- Selection of minimum water quality parameters within the available time and resources.

\section{B. Site Selection}

Seven sampling sites along Hlaing river and seven stations inlet drain were selected for the collection of water samples within low flow period (January and Febuary). The geographic co-ordinates of these sampling stations were taken by hand held Geological Positioning System (GPS) device and their distances (set river 1 as $0 \mathrm{~km}$ ).

\section{TEST RESUlTS AND DisCUSSION}

Physical parameters such as temperature, dissolved solid and total solid and chemical parameters such as $\mathrm{pH}$, BOD, COD, Salinity and Arsenic were examined for water quality characterization. Test results of individual water quality parameters for the selected stations along the river reach and inlets during the low flow season were plotted in Figure 2 to 11.

In this study, observations were carried out in small place and the same time and duration within only two months. It was found that Temperature values of all observations are almost constant in each and every station.

$\mathrm{pH}$ values at all river stations and almost all the inlets lie between 6.5 to 8.5 . Therefore water quality status of Hlaing River is neither acidic nor basic. The standard of surface water for any purpose in-terms of $\mathrm{pH}$ is 6.5-8.5, in that respect; the tested values which are graphically shown in Figure 3. indicate slightly acidic water but still in the range for the different uses for the river.

DO values of all river stations are less than the requirements for conservation of living environment (5 $\mathrm{mg} / \mathrm{l}$ ) and all inlet stations are much larger than the requirements for conservation of living environment.

The BOD level in the river at studied stations was found exceeding the permissible limit of $8 \mathrm{mg} / \mathrm{l}$ (Table 1.) for aquatic life.

COD value is higher than the permissible for aquatic live, $50 \mathrm{mg} / \mathrm{l}$ (Table 1.) in almost all the river stations.

\section{CONCLUSIONS}

It is founded that $\mathrm{pH}$ values are between 6.5 to 8.5 and suitable for drinking, irrigation and aquatic life. BOD values are higher than the $8 \mathrm{mg} / \mathrm{l}$ in most of the river stations and much higher than in all the inlet streams. COD is also higher than maximum limits of $50 \mathrm{mg} / \mathrm{l}$ for aquatic life in most of the river stations and inlets. It can be noted that water quality of the Hlaing river and especially in its tributary streams deteriorates and is not good even for aquatic life. DO values are higher than the minimum requirements for aquatic life in most of the river stations but lower than the minimum limit only in a few observations of river two and inlet two stations. Salinity values are higher than in most of the river stations depending on tidal conditions.

Degradation of water quality of the Hlaing river was found especially in downstream stations and seriously in almost all the inlet streams. BOD and COD values in all the inlet streams are higher than requirements of water quality standards for different uses. Salinity values are much higher in the downstream of the river due to tidal effects. $\mathrm{pH}$ and DO values are within the acceptable limit for the aquatic life in most of the river stations and some inlet streams. 


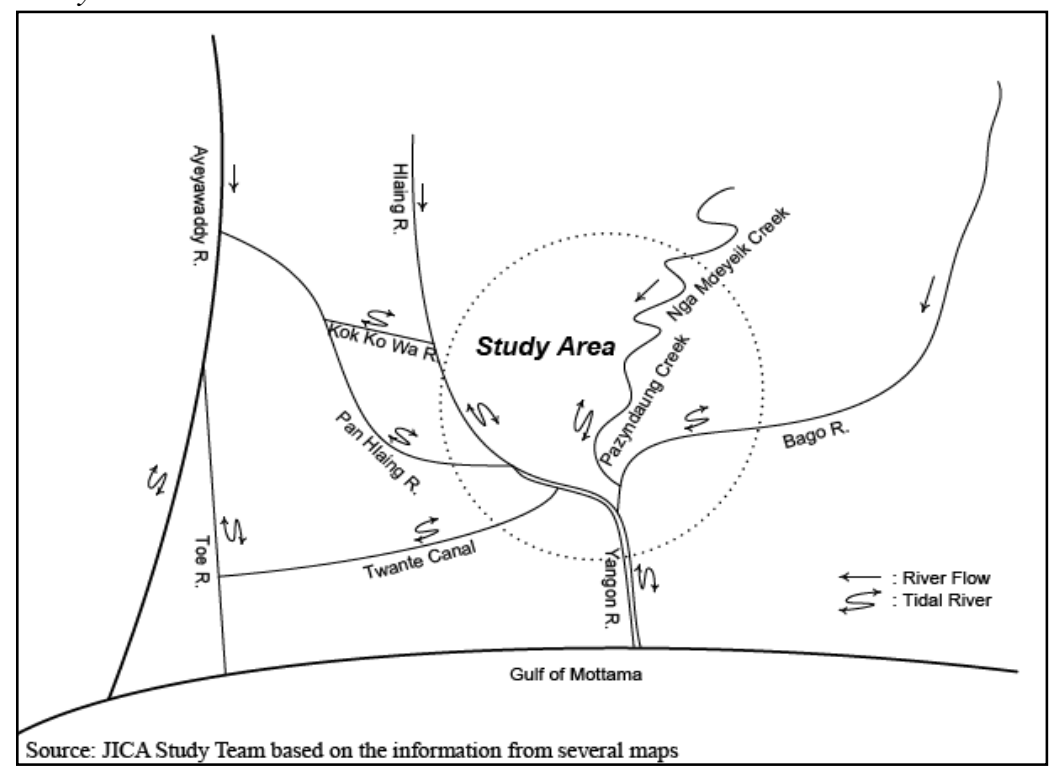

Figure.1 Schematic diagram of river system around Yangon

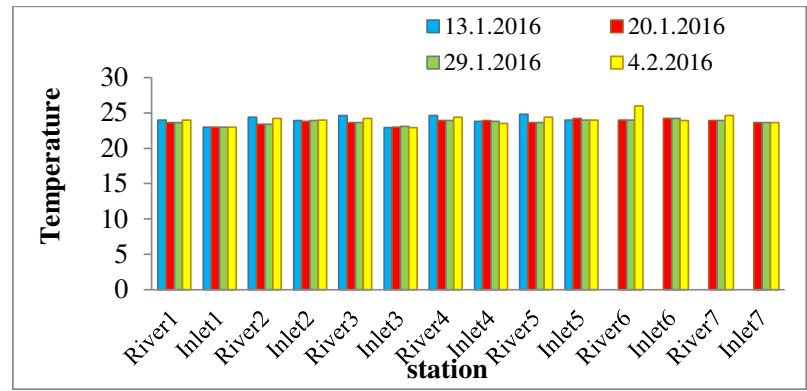

Figure. 2 Temperature variation of river and inlet stations

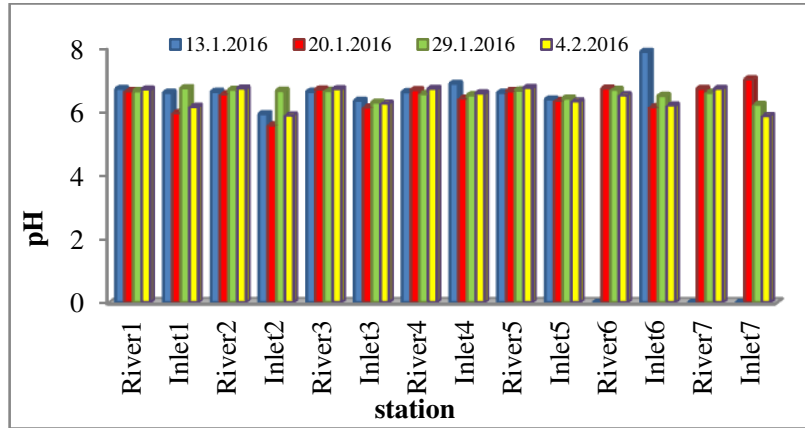

Figure. $3 \mathrm{pH}$ variation of river and inlet stations

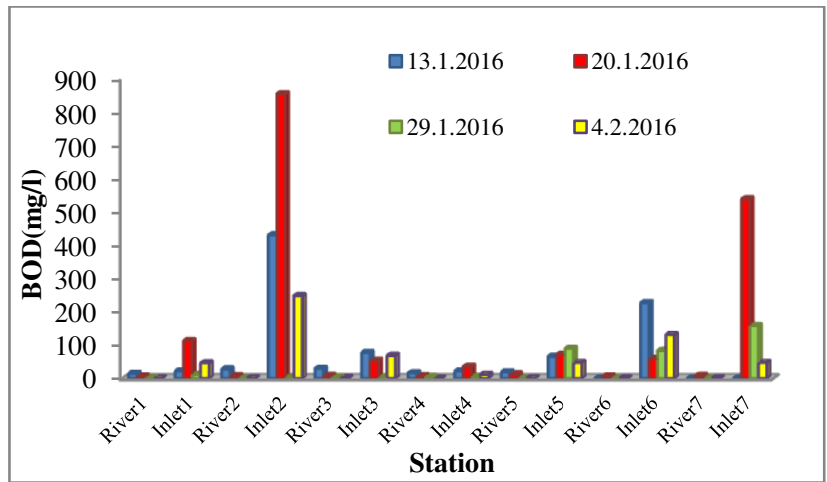

Figure.4 BOD variation of river and inlet stations 
The Third International Conference on Civil Engineering Research (ICCER)

August $1^{\text {st }}-2^{\text {nd }}$ 2017, Surabaya - Indonesia

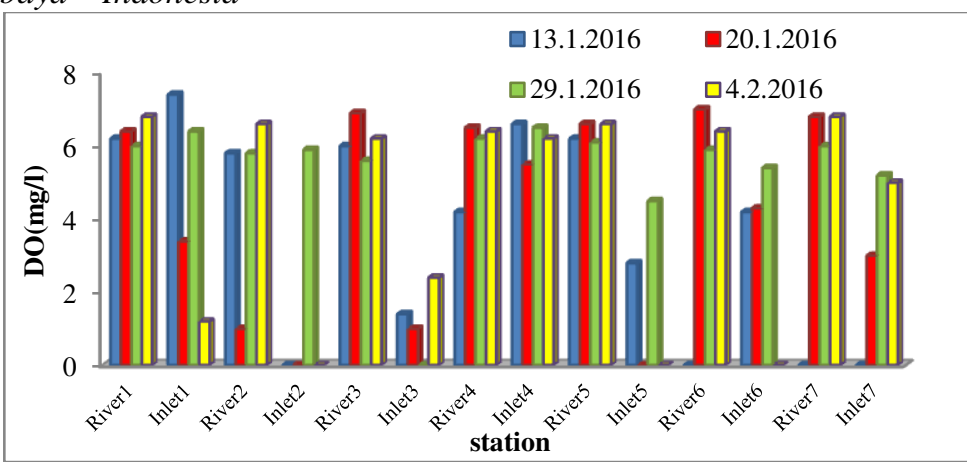

Figure. 5 DO variation of river and inlet stations

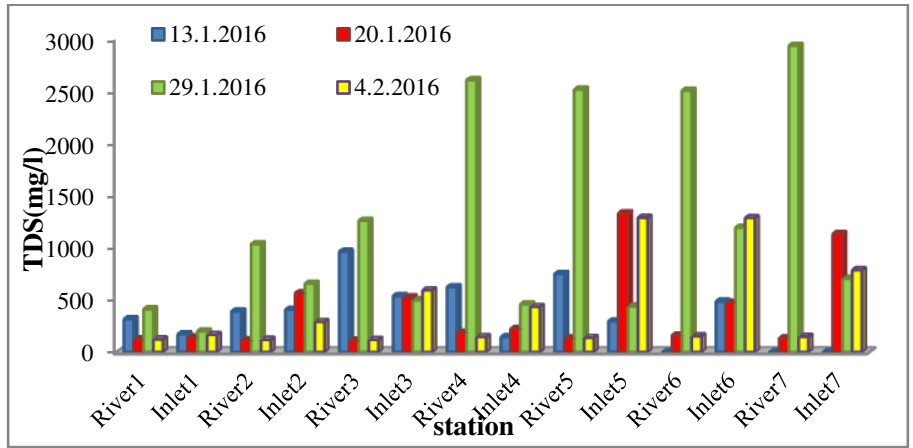

Figure. 6 TDS variation of river and inlet stations

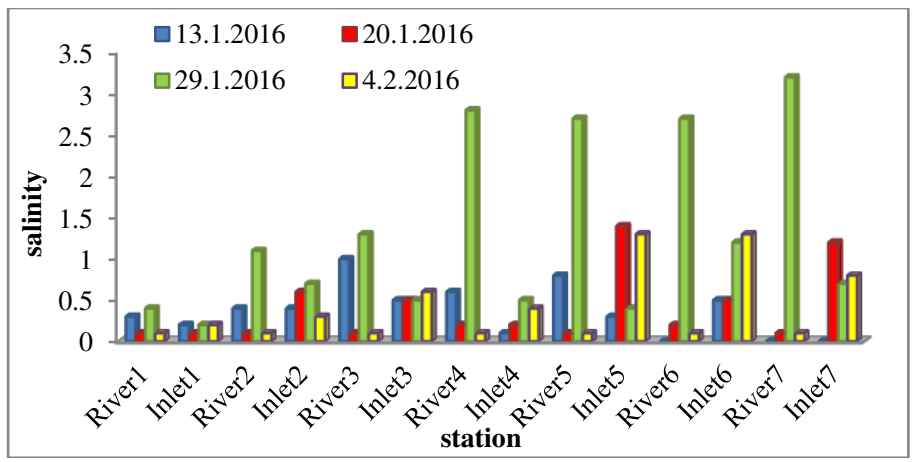

Figure. 7 Salinity variation of river and inlet stations

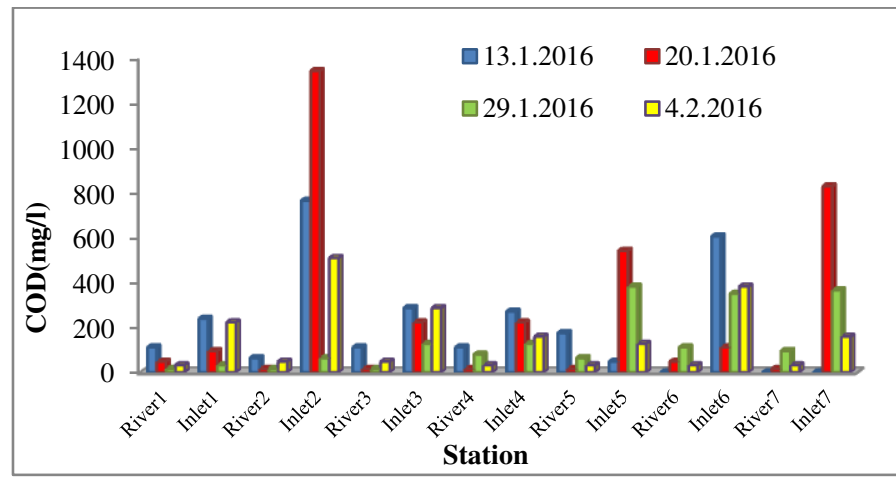

Figure. 8 COD variation of river and inlet stations 
The Third International Conference on Civil Engineering Research (ICCER)

August $1^{\text {st }}-2^{\text {nd }}$ 2017, Surabaya - Indonesia

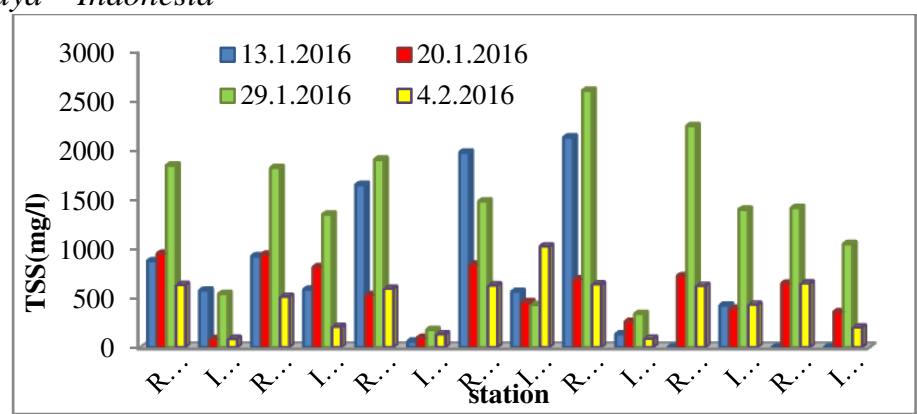

Figure. 9 TSS variation of river and inlet stations

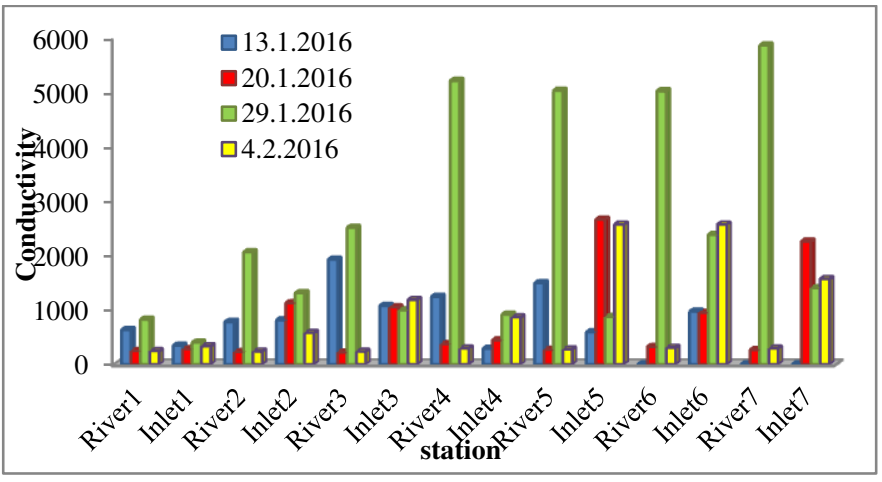

Figure. 10 Conductivity variation of river and inlet stations

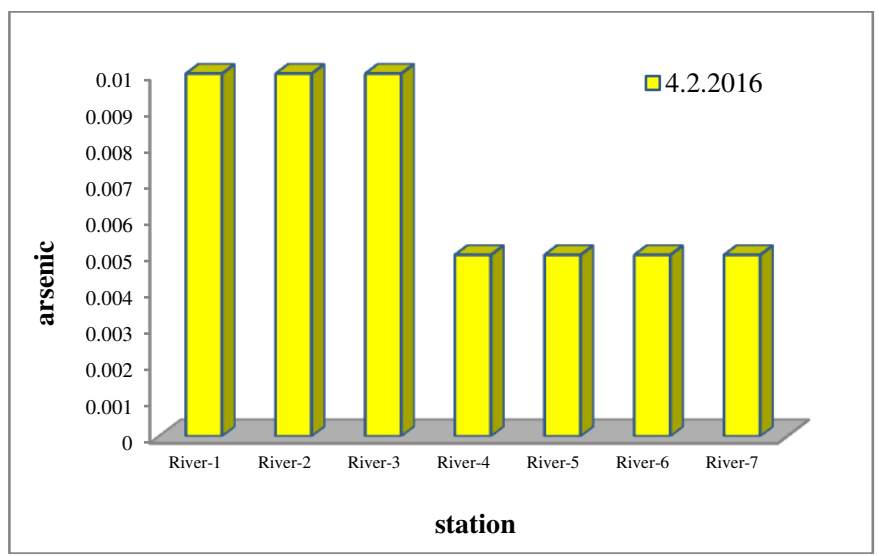

Figure. 11 Arsenic variation of river and inlet stations 
The Third International Conference on Civil Engineering Research (ICCER)

August $1^{\text {st }}-2^{\text {nd }}$ 2017, Surabaya - Indonesia

Pakistan Water Quality Guidelines for Different Water Uses

\begin{tabular}{|c|c|c|c|c|}
\hline \multirow{2}{*}{ Water Quality Parameter } & \multirow{2}{*}{ Unit } & \multicolumn{3}{|c|}{ Water Uses } \\
\hline & & Drinking & Aquatic & Irrigation \\
\hline $\begin{array}{l}\text { Total Dissolved Solids } \\
\text { (TDS) }\end{array}$ & $\mathrm{mg} / \mathrm{l}$ & 800 & 1000 & 1000 \\
\hline Electric Conductivity (EC) & $\mu \mathrm{S} / \mathrm{cm}$ & 1250 & 1500 & 1500 \\
\hline \multirow[t]{2}{*}{$\mathrm{pH}$} & Minimum & 6.5 & 6.5 & 6.4 \\
\hline & Maximum & 8.5 & 8.5 & 8.4 \\
\hline $\begin{array}{l}\text { Total Kjeldhal Nitrogen } \\
\text { (TKN) }\end{array}$ & $\mathrm{mg} / \mathrm{l}$ & $0.5^{*}$ & $1.2 *$ & N/A \\
\hline $\begin{array}{c}\text { Sodium Adsorption Ratio } \\
\text { (SAR) }\end{array}$ & & N/A & N/A & 8 \\
\hline $\begin{array}{l}\text { Residual Sodium } \\
\text { Carbonate (RSC) }\end{array}$ & $\mathrm{meq} / \mathrm{l}$ & N/A & N/A & 2.3 \\
\hline Dissolved Oxygen (DO) & $\mathrm{mg} / \mathrm{l}$ & $>6$ & $>5$ & $>4$ \\
\hline $\begin{array}{l}\text { Biochemical Oxygen } \\
\text { Demand (BOD) }\end{array}$ & $\mathrm{mg} / \mathrm{l}$ & 2 & 8 & 8 \\
\hline $\begin{array}{c}\text { Chemical Oxygen Demand } \\
\text { (COD) }\end{array}$ & $\mathrm{mg} / \mathrm{l}$ & $25^{*}$ & $50 *$ & $70 *$ \\
\hline Coliform Bacteria (total) & No./100 ml & 50 & 1000 & 1000 \\
\hline Coliform Bacteria (fecal) & No./100 ml & 20 & 200 & 500 \\
\hline Total Hardness & $\begin{array}{l}\mathrm{mg} / \mathrm{l} \text { as } \\
\mathrm{CaCO}_{3}\end{array}$ & 300 & N/A & N/A \\
\hline Chloride $(\mathrm{Cl})$ & $\mathrm{mg} / \mathrm{l}$ & 250 & N/A & 100 \\
\hline Sodium $(\mathrm{Na})$ & $\mathrm{mg} / \mathrm{l}$ & 200 & N/A & N/A \\
\hline
\end{tabular}

\section{REFERENCES}

[1] Environmental Protection Agency. 2001. "Parameters of Water Quality", December 2014 <https://www.epa.ie/pubs/advice/ water/quality/Water_Quality.pdf>

[2] Gilbert, M. 1991. "Introduction to Environmental Engineering and Science", Printice Hall, Inc.

[3] Anderson, A., Nagar, R. and Sarkar, S. (2007). "Spatial and temporal trends in surface water quality in a segment of the San
Antonio River", Texas. Developments in Environmental Sciences, 5: 591-608.

[4] R.M.Bhardwaj. (2005). "Water quality monitoring in Indiaachievements and constraints", Environmental International Work Session on Water Statistics, Vienna, 1-12.

[5] Muhammad Tousif Bhatti (2006). "Srtrategic analysis of spatial and temporal water quality of river chenab and its management", p-91.

[6] Japan international cooperation agency (jica), "Report on the project for the strategic urban development plan of the greater yangon (2013)" 